\title{
PENGARUH PEMBERIAN RHODAMIN B PERORAL SUBAKUT TERHADAP PERUBAHAN KETINGGIAN MUKOSA GASTER TIKUS PUTIH GALUR WISTAR ( Rattus norvegicus Strain Wistar)
}

\author{
Pravangesta Anggit Anjasmara ${ }^{1}$, Muhammad Fadhol Romdhoni', Mustika Ratnaningsih ${ }^{2}$ \\ ${ }^{1}$ Mahasiswa Fakultas Kedokteran, Universitas Muhammadiyah Purwokerto \\ ${ }^{2}$ Dosen Fakultas Kedokteran, Universitas Muhammadiyah Purwokerto
}

\begin{abstract}
ABSTRAK
Latar Belakang: Rhodamin B merupakan zat pewarna sintetis yang digunakan untuk pewarna tekstil, namun banyak disalahgunakan sebagai zat pewarna makanan. Hal ini sangat berbahaya bagi kesehatan karena Rhodamin B mengandung zat kimia yang berbahaya dan reaktif. Jika di konsumi dalam jangka panjang maka akan menyebabkan iritasi saluran cerna dan mengakibatkan gastritis.

Tujuan : Mengetahui pengaruh pemberian Rhodamin B peroral subakut terhadap perubahan ketinggian mukosa gaster tikus wistar.

Metode : Penelitian ini merupakan penelitian eksperimental dengan rancangan post test only with control design. Sampel berupa 24 tikus wistar jantan yang memenuhi kriteria inklusi dan eksklusi, kemudian diadaptasi dan dibagi secara acak menjadi 4 kelompok.K merupakan kelompok kontrol hanya diberikan makanan dan minuman standar. P1 diberi Rhodamin B peroral 3,5mg/kgBB, P2 diberi Rhodamin B peroral $7 \mathrm{mg} / \mathrm{kgBB}$, P3 diberi Rhodamin B peroral $14 \mathrm{mg} / \mathrm{kgBB}$. Setelah 30 hari dilakukan terminasi dan diambil organ gaster untuk dibuat preparat histopatologi.

Hasil : Rerata ketinggian mukosa gaster pada kelompok K=987,054 $\mu \mathrm{m}$; P1 $=732,170 \mu \mathrm{m} ; \mathrm{P} 2=587,187 \mu \mathrm{m} ; \mathrm{P} 3=525,967 \mu \mathrm{m}$. Hasil uji One Way Anova didapatkan perbedaan ketinggian mukosa pada semua kelompok $(\mathrm{P}<0,05)$ dan uji Post Hoc menggunakan uji $L S D$ didapatkan perbedaan yang bermakna pada K-P1 ( $\mathrm{P}=0,009)$, K-P2 ( $\mathrm{P}=0,000), \mathrm{K}-\mathrm{P} 3(\mathrm{P}=0,000), \mathrm{P} 1$ P3 $(\mathrm{P}=0,025)$. Tetapi tidak terdapat perbedaan bermakna pada P1-P2 ( $\mathrm{P}=0,103)$ dan $\mathrm{P} 2-\mathrm{P} 3(\mathrm{P}=0,479)$. Uji korelasi Spearman didapatkan hubungan negatif yang sangat kuat antara pemberian Rhodamin $\mathrm{B}$ dosis bertingkat terhadap perubahan ketinggian mukosa gaster $(\mathrm{r}=-0,781)$.
\end{abstract}

Kesimpulan : Pemberian Rhodamin B peroral subakut berpengaruh terhadap perubahan ketinggian mukosa gaster tikus wistar. Semakin tinggi dosis yang diberikan, semakin rendah ketinggian mukosa gaster.

Kata Kunci : rhodamin b, ketinggian mukosa gaster, peroral

\begin{abstract}
Background :Rhodamine B is synthetic coloring pigment used to give color in textiles industry. However, Rhodamine B is often abused as food coloring. This is very dangerous for health because Rhodamine B contains harmful and reactive chemicals. If this is consumed in long time, it can cause intestinal irritation and gastritis.

Aim :To prove the effect of giving orally subacute Rhodamine B to the changes of gastric mucosal thickness of wistar rats. Method :This study was experimental with post test only control group design. Samples were 24 male wistar rats that met inclusion and exclusion criteria, and were adapted and devided randomly into 4 groups. $\mathrm{K}$ was control group that was given standard food and standard drink. P1 was given Rhodamine B orally with dose of 3,5mg/kg. P2 was given Rhodamine B orally with dose of $7 \mathrm{mg} / \mathrm{kg}$. P3 was given Rhodamine B orally with dose of $14 \mathrm{mg} / \mathrm{kg}$. After 30 days the rats were terminated and their gasters were taken for histopathological examination.
\end{abstract}


Result :The mean of gastric mucosal thickness in each group was $\mathrm{K}=987,054 \mu \mathrm{m} ; \mathrm{P} 1=732,170 \mu \mathrm{m} ; \mathrm{P} 2=587,187 \mu \mathrm{m}$; $\mathrm{P} 3=525,967 \mu \mathrm{m}$. The result of One Way Anova test showed significant difference of mucosal thickness in all groups $(\mathrm{P}<$ $0,05)$ and Post Hoc test with LSD test showed significant differences in K-P1 ( $\mathrm{P}=0,009), \mathrm{K}-\mathrm{P} 2(\mathrm{P}=0,000), \mathrm{K}-\mathrm{P} 3(\mathrm{P}=0,000)$, $\mathrm{P} 1-\mathrm{P} 3(\mathrm{P}=0,025)$. While there were no significant differences in $\mathrm{P} 1-\mathrm{P} 2(\mathrm{P}=0,103)$ and $\mathrm{P} 2-\mathrm{P} 3(\mathrm{P}=0,479)$. Spearman correlation test showed a very strong negative relation between the giving of Rhodamine $\mathrm{B}$ in gradual doses to the changes of gastric mucosal thickness $(\mathrm{r}=-781)$.

Conclusion :Giving orally subacute Rhodamine B can cause gastric mucosal thickness change on wistar rats. The higher Rhodamin B dose given, the thinner the gastric mucosal thickness.

Keywords : rhodamine b, gastric mucosal thickness, orally

\section{PENDAHULUAN}

Rhodamin B merupakan zat pewarna berupa serbuk kristal berwarna hijau atau ungu kemerahan, tidak berbau, serta mudah larut dalam larutan warna merah terang berfluoresan sebagai bahan pewarna tekstil atau pakaian, namun pada kenyataannya Rhodamin B masih banyak disalahgunakan sebagai zat pewarna makananYamlean, (Paulina V. Y. 2011). Rhodamin B banyak ditemukan pada makanan jajanan seperti bubur delima, cendol, kolang-kaling, cincau, kerupuk, sirup, minuman kemasan, es doger, dan manisan (Winarno, F.G. 2004). Alasan penggunaan Rhodamin B sebagai bahan tambahan makanan antara lain karena harganya yang jauh lebih murah dibandingkan dengan zat warna pangan yang aman bagi kesehatan dan juga kurangnya pengetahuan produsen industri rumah tangga tentang zat pewarna apa saja yang diperbolehkan dan yang tidak diperbolehkan pada makanan (Winarno, F.G. 2004).

Serangkaian penelitian telah dilakukan untuk membuktikan penggunaan Rhodamin B sebagai bahan pewarna makanan. Penelitian pada tahun 2003 di kabupaten Bandung di temukan Rhodamin B pada kerupuk, jeli/agar-agar, aromanis, dan minuman dalam kadar antara 7.841-3.226,55 ppm (Trestiati, M. 2003). Penelitian pada tahun 2004, ditemukan $67 \%$ cabe merah giling yang mengandung Rhodamin B di pasar-pasar tradisional di DKI Jakart (Djarismawati, Sugiharti., Nainggolan, R. 2004). Penelitian pada tahun 2014 ditemukan jajanan yang mengandung Rhodamin B sebanyak 15 sampel di pasar tradisional kota Bandar Lampung (Permatasari, A., Susantiningsib, T., Kurniawaty, E. 2014)

Rhodamin B berbahaya bagi kesehatan manusia karena sifat kimia dan kandungan logam beratnya.Rhodamin B mengandung senyawa klorin
(Cl).Senyawa klorin merupakan senyawa halogen yang berbahaya dan reaktif.Selain itu, Rhodamin B juga memiliki senyawa pengalkilasi (CH3-CH3) yang bersifat radikal sehingga dapat berikatan dengan protein, lemak, dan DNA dalam tubuh. Jika di konsumi dalam jangka panjang maka akan menyebabkan iritasi saluran cerna dan mengakibatkan perubahan ketinggian mukosa gaster. ${ }^{6}$ Oleh karena itu, penelitian ini penting dilakukan untuk mengetahui pengaruh pemberian Rhodamin $\mathrm{B}$ terhadap perubahan ketinggian mukosa gaster tikus wistar.

\section{METODE}

Penelitian ini merupakan penelitian eksperimental dengan rancangan post test only with control design. Penelitian ini dilakukan pada bulan April-Mei 2017 di Laboratorium Farmakologi Fakultas Kedokteran Universitas Muhammadiyah Purwokerto dan Laboratorium Riset Fakultas Kedokteran Universitas Jendral Soedirman.Sampel berupa 24 tikus wistar jantan yang memenuhi kriteria inklusi dan eksklusi, kemudian diadaptasi selama 7 hari dan dibagi secara acak menjadi 4 kelompok. K merupakan kelompok kontrol hanya diberikan makanan dan minuman standar tanpa diberi Rhodamin B. P1 diberi Rhodamin B peroral dengan dosis 3,5mg/kgBB, P2 diberi Rhodamin B peroral dengan dosis $7 \mathrm{mg} / \mathrm{kgBB}$, P3 diberi Rhodamin B peroral dengan dosis $14 \mathrm{mg} / \mathrm{kgBB}$. Setelah 30 hari perlakuan, kemudian dilakukan terminasi dan diambil organ gaster untuk dibuat preparat histologi.Organ lambung difiksasi dengan menggunakan larutan Netral Buffer Formalin 10\%.Pengecatan jaringan gaster tikus menggunakan pewarna Hematoxylin Eosin (HE).Kemudian preparat tersebut diamati dengan mikroskop cahaya pembesaran 40x dalam 
5 lapangan pandang, ketinggian mukosa diukur dengan menggunakan software ImageJ.

\section{HASIL}

\begin{tabular}{|c|c|c|c|c|}
\hline & Kontrol & 3,5 & 7 & 14 \\
\hline \multirow{4}{*}{$\begin{array}{c}\text { Ketinggian } \\
\text { Mukosa } \\
\text { Gaster } \\
(\mu \mathrm{m})\end{array}$} & 835.419 & 828.491 & 682.436 & 444.428 \\
\cline { 2 - 5 } & 1184.836 & 677.344 & 560.236 & 381.256 \\
\cline { 2 - 5 } & 1259.375 & 645.829 & 544.118 & 657.212 \\
\cline { 2 - 5 } & 670.723 & 761.482 & 636.243 & 536.321 \\
\cline { 2 - 5 } & 902.223 & 524.892 & 492.689 & 606.756 \\
\hline $\begin{array}{c}\text { Rata-rata } \\
(\mu \mathrm{m})\end{array}$ & 978.054 & 732.170 & 587.187 & 525.967 \\
\hline
\end{tabular}

Tabel IV.1. Data Ketinggian Mukosa Gaster Rata-rata ketinggian mukosa pada kelompok kontrol adalah 987,054 $\mu \mathrm{m}$, kelompok perlakuan dosis 3,5 mg/kgbb adalah 732,170 $\mu \mathrm{m}$, kelompok perlakuan dosis $7 \mathrm{mg} / \mathrm{kgbb}$ adalah 587,187 $\mu \mathrm{m}$ dan kelompok perlakuan dosis $14 \mathrm{mg} / \mathrm{kgbb}$ adalah $525,967 \mu \mathrm{m}$.

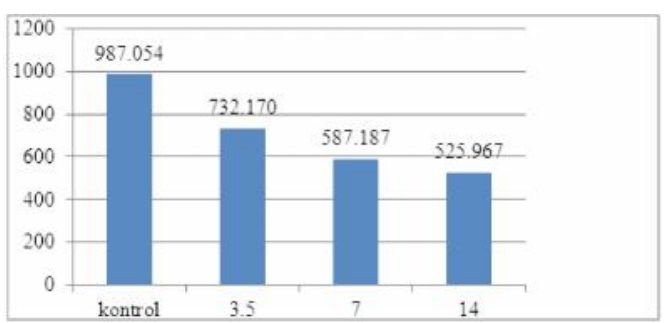

Gambar IV.1. Rata-rata ketinggian mukosa gaster kelompok kontrol, kelompok 3,5 mg/ kgbb, kelompok 7 mg/kgbb dan kelompok 14 $\mathrm{mg} / \mathrm{kgbb}$.

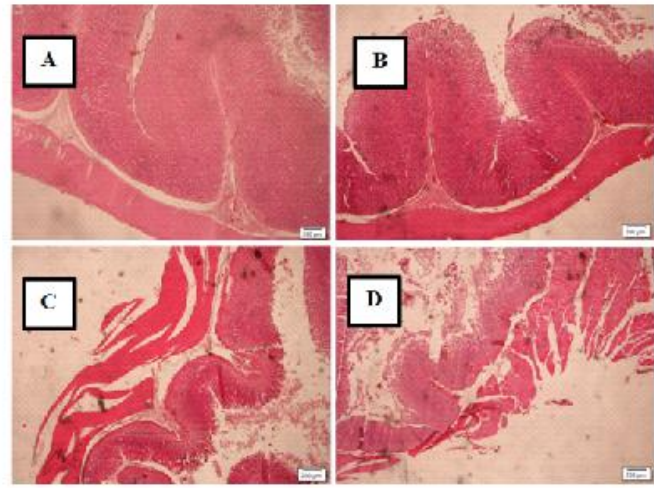

Gambar IV.2. Histologis gaster tikus bagian korpus setelah perlakuan dengan perbesaran 40x. A) Mukosa gaster tikus kelompok kontrol. B) Mukosa gaster tikus kelompok perlakuan 3,5 $\mathrm{mg} / \mathrm{kgbb}$. C) Mukosa gaster tikus kelompok perlakuan $7 \mathrm{mg} / \mathrm{kgbb}$. D) Mukosa gaster tikus kelompok perlakuan 14 $\mathrm{mg} / \mathrm{kgbb}$.

\section{Analisis Data}

Uji normalitas data menggunakan Shapirowilk didapatkan data terdistribusi normal (P $>0,05)$, uji homogenitas ketinggian mukosa gaster menggunakan Levene's Test didapatkan data homogen ( $\mathrm{P}>0,05)$, oleh karena itu dilanjutkan dengan uji parametrik One Way Anova. Pada uji One Way Anova didapatkan perbedaan yang signifikan antara kelompok kontrol dan kelompok perlakuan $(\mathrm{P}=$ 0,000), kemudian dilanjutkan dengan uji Post Hoc dengan menggunakan uji LSD. Hasilnya menunjukkan bahwa terdapat perbedaan yang signifikan pada hampir setiap kelompok $(\mathrm{P}<0,05)$ yaitu, antar kelompok kontrol dengan kelompok perlakuan 3,5 mg/kgbb $(\mathrm{P}=0,009) ; 7 \mathrm{mg} / \mathrm{kgbb}$ $(\mathrm{P}=0,000)$; dan $14 \mathrm{mg} / \mathrm{kgbb}(\mathrm{P}=0,000)$, kelompok perlakuan 3,5 mg/kgbb dengan kelompok perlakuan $14 \mathrm{mg} / \mathrm{kgbb}(\mathrm{P}=0,025)$. Beberapa hasilnya tidak terdapat perbedaan yang signifikan $(\mathrm{P}>0,05)$ yaitu, antar kelompok perlakuan 3,5 $\mathrm{mg} / \mathrm{kgbb}$ dengan kelompok perlakuan $7 \mathrm{mg} / \mathrm{kgbb}(\mathrm{P}=0,103)$ dan kelompok perlakuan $7 \mathrm{mg} / \mathrm{kgbb}$ dengan kelompok perlakuan $14 \mathrm{mg} / \mathrm{kgbb}(\mathrm{P}=0,479)$. Kemudian dilakukan uji korelasi antara kedua variabel dengan menggunakan uji Spearman. Pada uji korelasi Spearman antar pemberian Rhodamin B dosis bertingkat terhadap perubahan ketinggian mukosa didapatkan hasil korelasi berlawanan arah yang sangat kuat $(\mathrm{r}=-0,781)$. Sehingga semakin tinggi dosis Rhodamin B yang diberikan maka ketinggian mukosa gaster akan semakin menurun.

\section{DISKUSI}

Ketinggian mukosa gaster diukur dari lapisan teratas berupa epitel yaitu epitel silindris selapis hingga lapisan terbawah berupa lapisan muskularis mukosa. ${ }^{7}$ Hasil penelitian ini menunjukkan bahwa pemberian Rhodamin B peroral subakut pada tikus putih galur wistar (Rattus norvegicus) berpengaruh terhadap perubahan ketinggian mukosa gaster $(\mathrm{P}<0,05)$, dan hubungan antara pemberian Rhodamin B dengan dosis yang semakin tinggi berpengaruh secara berlawanan terhadap ketinggian mukosa gaster, dimana semakin tinggi dosis 
Rhodamin B yang diberikan maka semakin menurun ketinggian mukosa gaster.

Sesuai dengan teori bahwa pemberian bahan toksik secara terus menerus akan mengakibatkan sel melakukan adaptasi terhadap stressor dari luar, diantaranya dengan melakukan respon berupa atrofi, hipertrofi, hiperplasia, dan metaplasia. Salah satu bentuk adaptasi terhadap stressor dari luar yaitu berupa atrofi, jika sel mengalami atrofi maka akan terjadi penurunan dari ukurannya (Sander, Mochamad Aleq. 2010). Hal tersebut berhubungan dengan kejadian kerusakan pada gaster. Gaster yang terpapar bahan toksik secara terus menerus berakibat terjadinya kerusakan gaster. Kerusakan gaster antara lain berupa gastritis dan tukak peptik. Gastritis dapat diklasifikasikan menjadi gastritis erosif dan gastritis non erosif.Gastritis erosif biasanya bersifat akut dan ditandai oleh defek mukosa superfisial (erosi). Defek ini disebabkan oleh zat kimia dan obat misalnya aspirin, gangguan sirkulasi, atau bakteri misalnya Helicobacter pylori.

Gastritis nonerosif terdapat dalam dua bentuk: atrofik, bentuk yang lebih sering, atau hipertrofik, bentuk yang sangat jarang. Teradapat dua jenis gastritis atrofik, yaitu gastritis antrum dan gastritis fundus.Keduanya menunjukkan gambaran yang serupa yaitu mukosa yang mengandung lebih sedikit kelenjar sehingga lebih tipis dari pada mukosa normal. Tukak peptik adalah penyakit multifaktor yang ditandai oleh defek dalam pada mukosa yang meluas ke submukosa, dan bahkan ke muskularis lambung. Perluasan tukak melalui lapisan serosa menyebabkan perforasi dan akhirnya peritonitis. Dari semua jenis kerusakan pada gaster, baik gastritis maupun tukak peptik, akan mengakibatkan penurunan dari ketinggian lapisan mukosa gaster. Menurunnya ketinggian mukosa gaster berakibat pula menurunnya sistem pertahanan dari mukosa gaster, karena mukosa gaster mengandung banyak jumlah prostaglandin yang mengatur pengeluaran dari mukosa bikarbonat dan mukus serta menghambat sekresi sel parietal, dan sangat penting dalam mengatur aliran darah dan perbaikan dari sel epitel.

Hasil dari penelitian ini yang didukung oleh beberapa teori dan juga beberapa penelitian terdahulu membuktikan bahwa Rhodamin B merupakan zat pewarna makanan yang berbahaya untuk dikonsumsi.Sesuai dengan teori yang mengatakan bahwa Rhodamin B merupakan zat pewarna makanan yang berbahaya karena sifat kimia dan kandungan logam beratnya.Rhodamin B mengandung senyawa klorin $(\mathrm{Cl})$.Senyawa klorin merupakan senyawa halogen yang berbahaya dan reaktif. Jika tertelan, maka senyawa ini akan berusaha mencapai kestabilan dalam tubuh dengan cara mengikat senyawa lain dalam tubuh, hal ini lah yang bersifat racun bagi tubuh.

\section{KESIMPULAN}

Pemberian Rhodamin B peroral subakut berpengaruh terhadap perubahan ketinggian mukosa gaster tikus putih galur wistar (Rattus norvegicus). Pemberian Rhodamin B mengurangi ketinggian mukosa gaster dan dengan semakin tinggi dosis Rhodamin B maka ketinggian mukosa gaster semakin menurun.

\section{DAFTAR PUSTAKA}

Yamlean, Paulina V. Y. 2011. Identifikasi dan Penetapan Kadar Rhodamin B pada Jajanan Kue Berwarna Merah Muda yang Beredar di Kota Manado. Jurnal Ilmiah Sains, 11 (2), 289-295.

Winarno, F.G. 2004. Kimia Pangan dan Gizi. Jakarta: PT Gramedia Pustaka

Trestiati, M. 2003. Analisis Rhodamin B pada Makanan dan Minum an Jajanan Anak SD. Bandung: Departemen Teknik Lingkungan Institut Teknologi Bandung.

Djarismawati, Sugiharti., Nainggolan, R. 2004. Pengetahuan Perilaku Pedagang Cabe Merah Giling dalam Penggunaan Rhodamine B di Pasar Tradisional di DKI Jakarta. Jurnal Ekologi Kesehatan, 3:7-12.

Permatasari, A., Susantiningsih, T., Kurniawaty, E. 2014. Identifikasi Zat Pewarna Rhodamin B Dalam Jajanan Yang Dipasarkan Di Pasar Tradisional Kota Bandar Lampung. Jurnal Penelitian. Lampung: Fakultas Kedokteraan Universitas Lampung.

Sentra Informasi Keracunan Nasional (SIKerNas). 2015. Bahaya Rhodamin B Sebagai Pewarna pada Pangan. Badan POM. Available from: http://ik.pom.go.id/v2015/artikel/BahayaRhodamin-B-sebagai-Pewarna-padaMakanan.pdf [Diakses 16 Februari 2017]1992 
Eroschenko, Victor P. 2015. Atlas Histologi diFiore Edisi 12. Jakarta: EGC. Hal: 286-289.

Sander, Mochamad Aleq. 2010. Atlas Berwarna Patologi Anatomi. Jakarta: Rajawali Pers. 8-11; 120-122.

Isselbacher., dkk. 2012. Harrison Prinsip-prinsip Ilmu Penyakit Dala Edisi 13. Jakarta: EGC 